\title{
The Fading Away of the Bilbao Effect: Bilbao, Denver, Helsinki, Abu Dhabi
}

\author{
By Gerardo del Cerro Santamaría*
}

\begin{abstract}
This paper uses several cases of attempted urban regeneration via cultural megaprojects to show the drawbacks and failures of so-called Bilbao Effect: a model of urban revitalization based on iconic architecture that became commonplace among urban managers worldwide after the alleged success of the Bilbao Guggenheim upon its opening in 1997. It is argued that cultural megaprojects are in fact vehicles for a property-led urban revitalization strategy with substantial disadvantages for cities and regions. The impacts of these iconic buildings on the urban fabric are often unintended and negative. The relative success of Bilbao has been hard to replicate elsewhere because urban leaders in most cities have overlooked the intrinsic limitations of iconic buildings to effect urban socio-economic regeneration. Urban leaders elsewhere also failed to examine and understand the specific socio-economic and political context in Bilbao as well as the overall local revitalization strategy of which the Guggenheim was just one element among many. As a result of the failure and the fading away of the Bilbao effect, the Guggenheim Foundation dream of museum franchises around the world, controlled by the Foundation and paid for by host cities, has not been realized.
\end{abstract}

\section{Introduction}

The influence of neoliberalism on urban areas under pressure to attract investors and become visible has led to a relatively uniform approach to urban policy across political and geographic boundaries. The "recipe" for urban economic improvement has focused on property-led regeneration even if such strategy has been presented as "cultural regeneration." Cities have been encouraging this strategy through zoning and megaproject-based investment in areas that can easily be redeveloped and are often populated by low-income and minority communities. In "entrepreneurial cities," heavy manufacturing was gradually replaced by niche real estate, service sector employment, tourism and culture. $^{2}$

Urban megaprojects (parks, art museums, sports stadia, convention centers) are intended to attract new investment and draw tourists and foot traffic to underutilized areas, thus increasing property values and triggering widespread gentrification. More and more cultural attractions, especially museums, are now the central part of urban development strategies for inner-city and other central

*U.S. Fulbright Award Recipient (Urban Planning), New York City, USA.

1. P. Healey, S. Davoudi and S. Tavsanoglu, Rebuilding the City: Property-led Urban Regeneration (London: Chapman \& Hall, 1992); S. Fainstein, The City Builders. Property Development in New York and London, 1980-2000 (Kansas: University Press of Kansas, 2001).

2. D. Harvey, "From Mangerialism to Entrepreneurialism: The Transformation in Urban Governance in Late Capitalism,” Geografiska Annaler 71, no. 1 (1989). 
development projects, pursuing an important economic aim and representing the overall project as a flagship or icon. ${ }^{3}$ Museums allow cities to advertise themselves as locations of arts and culture, which tends to attract wealthier individuals. In this way, neoliberal public space is a vehicle for economic development benefitting some populations to the detriment of others. ${ }^{4}$

Museums (such as those discussed in this paper) have become a part of urban planning strategies for redevelopment only recently. The Museum of Modern Art in Manhattan (Edward Durrell Stone, 1939) epitomized the "white cube" model of museum architecture and the International Style. The MoMa established the influence of modernism on cultural architecture. The MoMA continued to be the pre-eminent model for art display, but the beginning of sculptural form in museum design is Frank Lloyd Wright's Guggenheim, also in Manhattan, on $5^{\text {th }}$ Avenue. This building, in both its exterior and interior's curving galleries, inspired a lineage of sculptural museums in opposition to MoMA, including, notably, the Guggenheim Bilbao designed by Frank Gehry. ${ }^{5}$

Following Wright's Guggenheim, the next major museum in this category is Centre Pompidou (1977) designed by Richard Rogers and Renzo Piano. Hoping to renew the idea of Paris as a leading city of culture and art, the Pompidou shifted the role of the museum away from a purely educational institution. It was the main strategy of the Parisian government's attempt to redevelop the historic neighborhood of the Marais and it represented the beginnings in the era of iconic museums as a force of urban regeneration. ${ }^{6}$ In 2007, when Rogers won the Pritzker Prize, the jury said the Pompidou "revolutionised museums, transforming what had once been elite monuments into popular places of social and cultural exchange, woven into the heart of the city."

Thus, when the Guggenheim Foundation and Basque planners agreed to build a Guggenheim Museum in Bilbao in 1991, emblematic projects and cultural megaprojects were already playing an important role in the revitalization of cities in Europe (e.g. Paris, London) and the USA (e.g. Pittsburgh), ${ }^{8}$ and the key role of iconic architecture in changing a city's image was being discussed and was well understood among urban planners. Bilbao became a game-changer both because of the early success of the Gehry building in architectural circles, and also because the socio-political and socio-economic contexts (political unrest, deindustrialization and severe economic downturn), in a city unkown to most, added up to a good

3. B. Plaza and Silke N. Haarich, "Museums for Urban Regeneration? Exploring Conditions for their Effectiveness," Journal of Urban Regeneration and Renewal 2, no. 3 (2009): 259-271.

4. P. Snyder, Museums after Bilbao: Neoliberal Public Space at the Denver Art Museum (Wesleyan University, 2016); G. del Cerro Santamaría (ed.) Urban Megaprojects. A Worldwide View (Bingley: Emerald, 2013).

5. A. McClellan, The Museum from Boullée to Bilbao (Berkeley: The University of California Press, 2008); Snyder, "Museums after Bilbao: Neoliberal Public Space at the Denver Art Museum," 2016.

6. V. Newhouse, Towards a New Museum (New York: Monacelli Press, 1998).

7. R. Pogrebin, British Architect Wins 2007 Pritzker Prize (The New York Times, 28 March 2007) [Retrieved May 2018].

8. Smyth, Marketing the City. The Role of Flagship Developments in Urban Regeneration (London: Routledge, 2015). 
journalistic story that swiftly travelled around the world. This is how the "Cinderella" story (a museum puts the city on the map and rescues an urban economy in crisis) misleadingly spread out. ${ }^{9}$

\section{The Bilbao Effect in the World}

The Bilbao Effect can be succinctly defined as the attempts by a significant share of urban elites worldwide to build icons in their cities, largely based on a superficial and media-based understanding of the Bilbao case, which led many to firmly believe that a city in economic difficulties could be turned around just by iconic architecture. The Bilbao "Cinderella" story captivated many urban leaders. The Guggenheim Foundation received in those years numerous offers from cities in five continents to pay for the full cost of a building designed by Frank Gehry. Thus, the Bilbao effect transcended the discursive realm into the material world and many in cities around the world considered it possible to effect local transformations similar to Bilbao's by simply building a Guggenheim Museum.

The model of the global museum franchise envisioned by the Guggenheim seemed, for some time, to become a reality. Many urban officials contacted the Guggenheim Foundation with firm plans, though just a handful went beyond the initial conversations - Rio de Janeiro, Vilnius, Salzburg, Guadalajara and Taichung -- only to see negotiations end before reaching an agreement. The Guggenheim Foundation was able to openly advertise itself as a global art organization with a new, successful vision for the museum of the twenty-first century. ${ }^{10}$

The Foundation planned for a large Guggenheim museum on the waterfront in lower Manhattan, and it engaged Frank Gehry as the architect. His essentially complete designs for the building were showcased in 2001 at the Fifth Avenue museum, but these plans were disrupted by the economic downturn of the early 2000s and the September 11, 2001 attacks, which prompted reconsideration of any plans in New York.

Two outposts of the Guggenheim opened in Berlin (1997-2012) and Las Vegas (2001-2008), but they did not achieve much success and had to close. Abu Dhabi and Helsinki have been more recent and successful contenders. The Guggenheim Abu Dhabi (designed by Frank Gehry) has been built, is almost complete, and was expected to open in 2017, after several delays, but as of June 2019 it has not yet opened its doors. The Guggenheim Helsinki project unveiled the winning design in June 2015, following an international competition (Figures 6 and 7). However, in Fall 2016 the City of Helsinki voted to cancel the project due to increasing controversy and civic opposition. Plans seemed completed or near completion in 2016 for new cultural hubs centered on museums in Saudi Arabia (Mecca), Australia (Perth), Albania (Tirana) and Brazil (Belo Horizonte). What

\footnotetext{
2007).

9. G. del Cerro Santamaría, Bilbao. Basque Pathways to Globalization (London: Elsevier,

10. B. Alsdorf, Collections Curatorial Assistant for the Guggenheim Foundation (Guggenheim Foundation, 2002).
} 
became Eastern Europe's largest museum, the Mystetskyi Arsenal, with 50,000 square metres $(540,000 \mathrm{sq} \mathrm{ft})$ of exhibition space, opened fully in Kiev, Ukraine, in $2011 .{ }^{11}$

The Bilbao Effect was utilized to explain events whose causal relationship with the success of Gehry's building is not easy to prove. For instance, the alleged success of the Bilbao museum has been credited with the increased wave of museum construction, extension and reform in the United States in the past fifteen years. Critic L. A. Wilson argued that the museum in Bilbao "was widely credited with having sparked an economic boom in northern [sic] Spain" ${ }^{\text {"12 }}$ which other cities aimed to replicate. She quoted architecture critic and Editor-in-chief Robert A. Ivy of Architectural Record, who proclaimed that "Gehry's Bilbao has conflated cultural, economic, and political interests, alerting all to what a dazzling object in the cityscape can accomplish."13

The Guggenheim building in the Basque capital was also perceived as the beginning of a new era in which museums are thought of as monumental sculptures, potentially becoming the most important work in an institution's collection (Figures 1-3). Museum plans developed all over the United States, including New York (a new Guggenheim by Gehry and the Whitney extension by Rem Koolhaas); Philadelphia by Tadao Ando, Hartford, CT; Boston, Bellevue, WA; San Francisco, Denver, Saint Louis, Milwaukee, WI; Cincinnati, Savannah, GA; Kansas City, MO; Atlanta, GA; Austin, TX; Charlotte, NC.

According to a study from the University of Chicago, "between 1994 and 2008, 725 new arts facilities were built in America at a price of more than \$US 15 billion." " Even the 2008 recession couldn't stop the boom: according to the Art Newspaper, from 2007 to 2014, \$8.9 US billion was spent on museum expansions worldwide, and \$5 US billion in the United States alone. ${ }^{15}$

"To tour the museums and art galleries of the last two decades is to take in a whimsical menagerie of iconic creations: curls of Frank Gehry-built metal rippling through Cleveland and Seattle; neo-futuristic Zaha Hadid monuments alighting in Azerbaijan and Guangzhou like so many glossy alien motherships; Daniel Libeskind shards poking out of heritage buildings from Dresden to Toronto."16

Cultural megaproject construction was not limited to wealthy global cities like Paris, New York and London. Regional and small cities such as Biloxi, Mississippi, and Roanoke, Virginia, also attempted Bilbao-like urban transformations into cultural hubs via iconic museums. According to Joanna Woronkowicz, one of the

11. A. Klebnikov, Museums Inc. (Forbes, 8 January 2001).

12. A. Wilson Lloyd, “Architecture for Art's Sake,” Atlantic Monthly 287 (2001): 85-8.

13. R. Ivy, "Architecture for Art's Sake," quoted in A. Wilson Lloyd. Atlantic Monthly 287 (2001): 85-8.

14. Woronkowicz, J. et al. Building Better Arts Facilities: Lessons from a U.S. National Study (London: Routledge, 2015), 16.

15. E. Blakemore, Museum Building is Booming in the United States (Smithsonian.com, 11 April 2016).

16. Hune-Brown, Is this the End of Starchitecture? (Azure, 18 August 2017). 
authors of the University of Chicago study, "the people behind these buildings all had something in common: they had read Richard Florida and absorbed his message. Building a large, eye-popping museum wasn't an act of hubris; it was a civic duty."17

Nevertheless, the Bilbao Effect faced significant criticism and skepticism among numerous architecture and art connoisseurs. Chicago Tribune critic Blair Kamin noted that the rise of "starchitects" poses a broad set of questions about the impact of globalization on an art that is ultimately local:

"Should 15 or 20 starchitects be designing all the world's great buildings? What does it mean if every city has its Gehry, its Koolhaas, its Calatrava? Are the backers of these buildings simply seeking known commodities rather than taking genuine artistic risks? Can the stars tailor their style to a vast, crosscultural array of functions and places?",18

Architectural critic Witold Rybczynski asked whether the cities commissioning new museums by starchitects can become the next Bilbao in terms of visitors. He noted that attendance at the Experience Music Project in Seattle, designed by Frank Gehry for Paul Allen in 1996, decreased by a third eighteen months after the museum opened, while the number of visitors to the local art museum increased by more than a third during the same period. Recently a portion of the building was converted into a science-fiction museum. Despite its unusual architecture, consisting of colorful, rounded forms said to be inspired by electric guitars, the museum of rock music and Jimi Hendrix memorabilia, the Experience Music Project has not proven to be a success.

Rybczynski was "skeptical that designing in the full glare of public competitions encourages architects to produce better buildings. The charged atmosphere promotes flamboyance rather than careful thought, and favors the glib and obvious over the subtle and nuanced." 19 More recently, Rybczynski has argued that "perhaps the Bilbao effect should be called the Bilbao anomaly," since "the iconic chemistry between the design of a building, its image and the public turns out to be quite rare, and somewhat mysterious.",20

"Failed icons do not disappear though, which is indeed problematic. Since the Bilbao effect mistakenly teaches that unconventional architecture is a prerequisite for iconic status, clients have encouraged their architects to go to greater lengths to design buildings that are unusual, surprising and even shocking. The shock, however, will inevitably wear off, and 100 years from now most aspiring iconic constructions will resemble a cross between a theme park and the Las Vegas strip." ${ }^{21}$

17. Ibid.

18. B. Kamin, How Stellar are 'Starchitects'? (Chicago Tribune, 27 January 2002).

19. W. Rybczynski, “The Bilbao Effect," Atlantic Monthly 290, no. 2 (2002): 138-42.

20. Rybczynski, When Buildings Try Too Hard (Wall Street Journal, 22 November 2008).

21. Ibid, 29. 


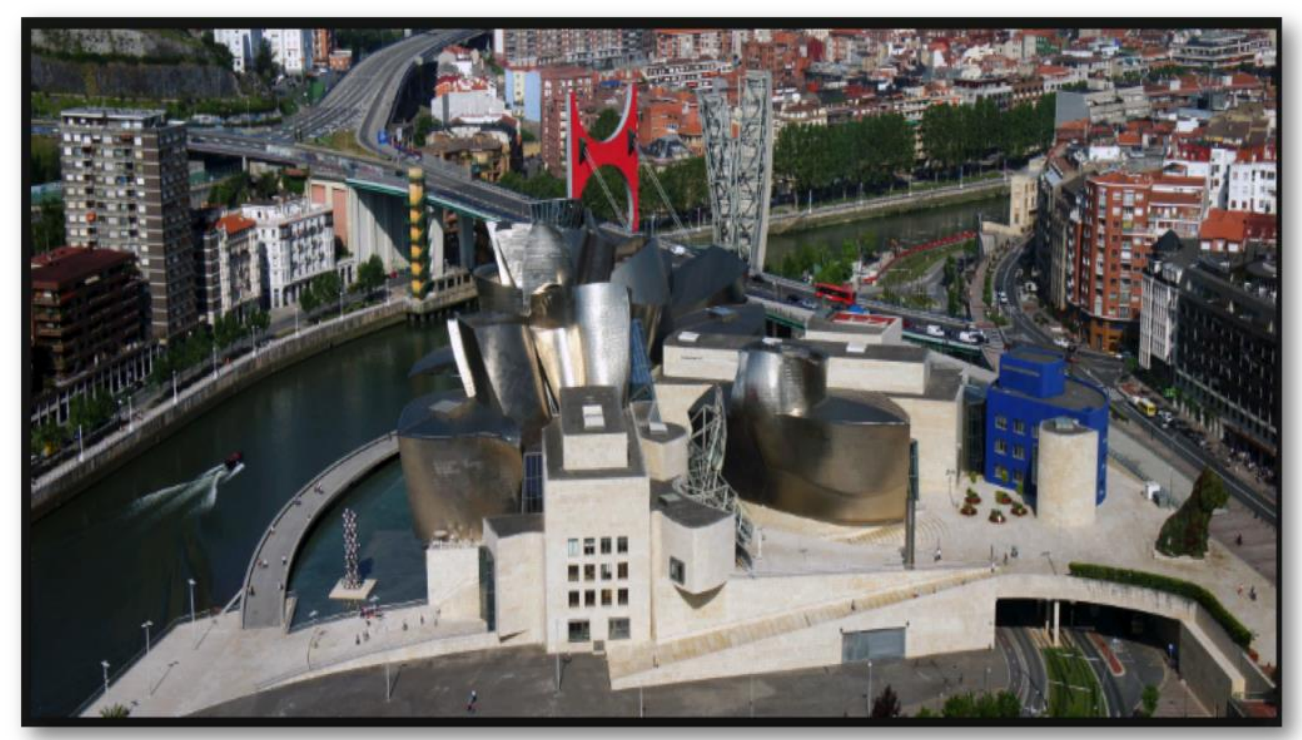

Figure 1. Aerial Photo of the Guggenheim Building (Frank Gehry, 1997) in Bilbao (Spain)

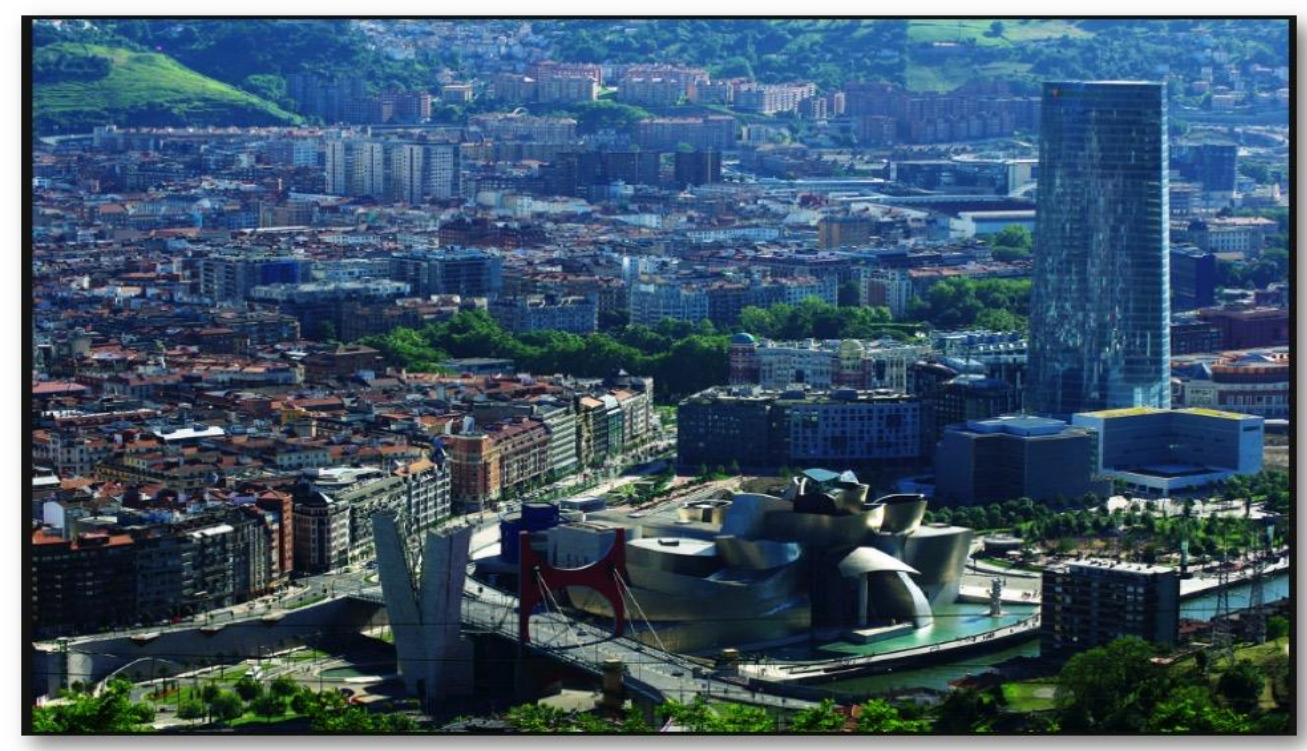

Figure 2. Panoramic View of the City of Bilbao with the Guggenheim Museum in Center Foreground 


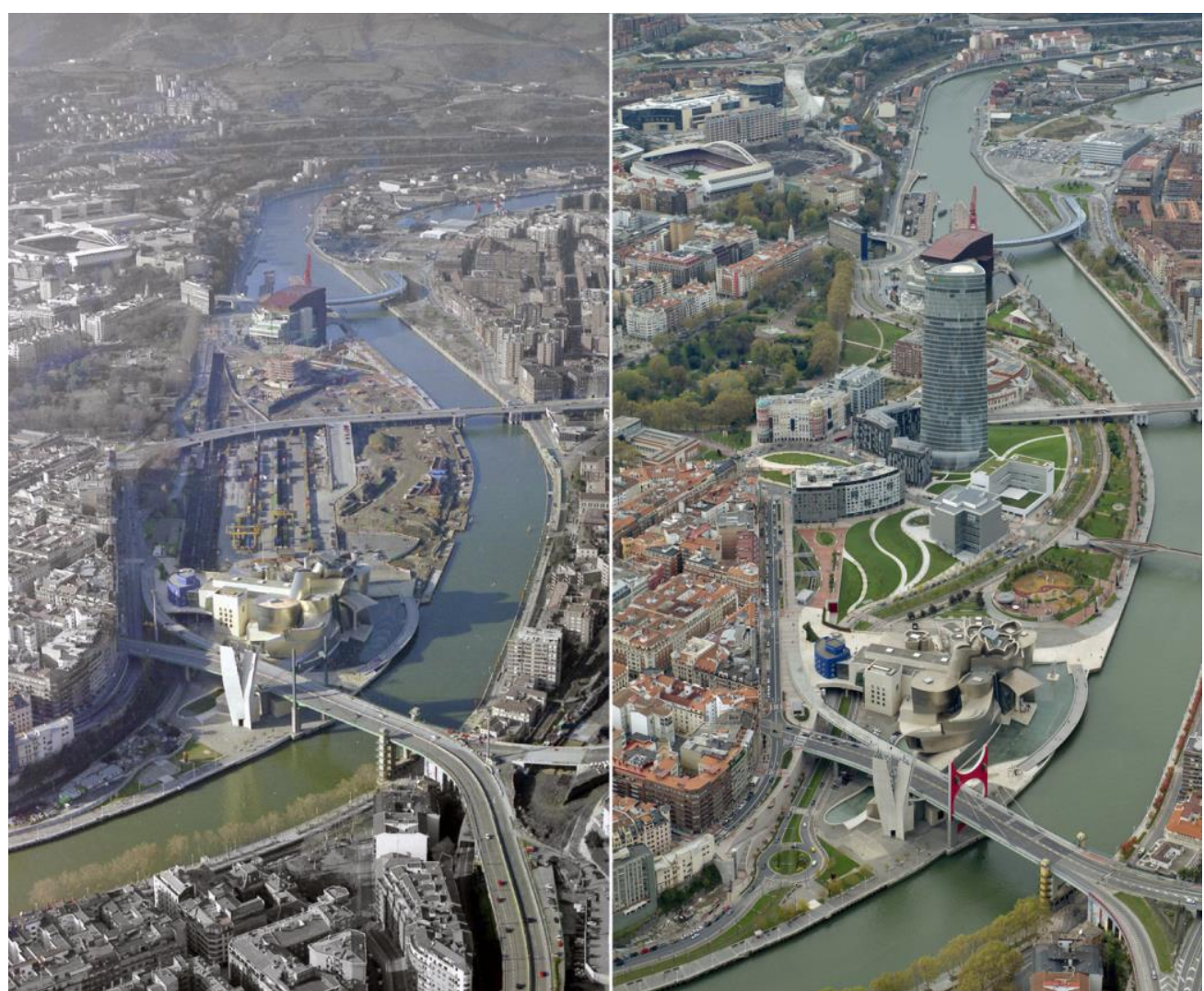

Figure 3. Aerial Photos of the Guggenheim Museum within the Abandoibarra Redevelopment in Downtown Bilbao, in Two Different Years: 2005 (left) and 2017 (right)

\section{The Case of the Denver Art Museum}

Both the Denver Art Museum (DAM) and its critics see the origins of the Hamilton Addition at Bilbao, after the director of the DAM visited the opening of the Bilbao Guggenheim and got captivated by what he saw: he "wanted one for Denver." 22 (Figures 4-5). The mayor of Denver was quoted predicting that the jumble of metal-clad, faceted geometric forms that made up architect Daniel Liebeskind's design (open in 2006) would "put us on the map as a world-class destination city,"23 a still unrealized wish today.

Our discussion on Denver follows Snyder (2016) as well as Lindsay (2013). ${ }^{24}$ There are abundant formal similarities between the two museums (Bilbao and Denver), including their material choice (titanium cladding), the selection of a star architect, and the construction of a daring sculptural structure. In addition to

22. J. Brown, New Denver Art Museum Reflects Rocky Mountains (PBS Newshour, October, 5, 2006).

23. W. Webb, “Architecture for Art's Sake," quoted in A. Wilson Lloyd. Atlantic Monthly 287 (2001): 85-8

24. Snyder, "Museums after Bilbao: Neoliberal Public Space at the Denver Art Museum," 2016; G. Lindsay, The Denver Art Museum and the Bilbao Effect (UC Berkeley, 2013). 
architectural similarities, the Hamilton Addition was intended to play a role in developing the long under-used Golden Triangle neighborhood to the south of the addition. The use of an international architect to garner attention at the Ponti Building suggests that the influence of the Guggenheim Bilbao on the DAM is indisputable. $^{25}$

The Hamilton Building was sold to the public as not just a building but as a symbol and an event. The power of architecture as icon is dependent on the "circulation of visual images, combined with an embodied, performed set of tourist practices on the part of architects and their professional critics and journalists." 26 That is, iconic architecture has a strong media presence and draws tourists to consume it visually. According to architectural theorist Charles Jencks, the iconic building

"need not be a great work of architecture, but it must be a captivating one. It has to move your viscera, whether you like it or not, and stay around as a memory image that attracts other thoughts into its orbit."27

As Lindsay remarks, using a building to represent a place is not new; the Eiffel Tower, the Sydney Opera House, even the Gothic Cathedrals are icons that draw people to visit them. "The Hamilton Addition stands out from the surrounding buildings, breaks with historical norms for art museums and civic centers, uses a new material for cladding, and defies gravity with its angles and cantilevers.",28

"But it is a break that has been vetted, successfully tried in Bilbao, Spain, and copied by cities across the United States. The selection committee had strong evidence in the Jewish Museum and Gehry's Bilbao that this could be a successful strategy." 29

Both local and global elements had an influence in the planning and design of The Hamilton Addition, which was an urban event, aiming at an international scale, because it intended to expand the global reach of Denver. Libeskind's design was simultaneously a tool for local urban planning and a symbol for the region of urban innovation.

"In a very basic way, the Museum is part of the urban fabric of Denver, and the Hamilton Building takes seriously its role at the urban level, seeking to connect the Civic Center and the Golden Triangle. It makes physical gestures towards downtown, with the prow pointing in that direction, while reducing 2016, 29.

25. Snyder, "Museums after Bilbao: Neoliberal Public Space at the Denver Art Museum,"

26. D. McNeill, The Global Architect: Firms, Fame and Urban Form (New York: Routledge, 2009), 82.

27. C. Jencks, The Iconic Building (New York, NY: Rizzoli, 2005), 54.

28. Lindsay, "The Denver Art Museum and the Bilbao Effect," 2013, 32.

29. Ibid, 36. 
its height near the residential Golden Triangle., ${ }^{30}$

Urban gentrification was an intended effect of the building. Urban leaders in Denver tried to transform the civic center of the city "from a place of homeless people into a place where the upper classes spend time." The success of the building at this is only partial, and property prices in the area have not significantly changed by effect of the building-led gentrification itself.

"Some of that is due to timing: although Denver's housing market did not crash as badly as it did in places like Las Vegas or Phoenix, it still experienced the slow-down in housing that affected the United States in the wake of the 2008 crash." 31

The museum received substantial criticism: about Libeskind's architectural style and decreasing quality of his work, about the ability of the building to work as an art museum, about the building's perceived failure as a space for exhibiting art.

"Criticism of sculptural museums contends that both the exterior architecture and the interior gallery spaces can distract museumgoers from fully appreciating the art within. The first concern is that the architecture upstages the art it contains, because visitors come to see the building instead of the art. The second exception critics take is that the architecture distracts visitors from viewing the art. This criticism is especially relevant for the Hamilton Addition." 32

While the Hamilton Addition received mostly negative criticism concerning Libeskind's style and its display of art, it received favorable comments regarding its relationship to urban space. Critics referred to the Hamilton Addition as a "surprisingly sensitive shaper of urban space," a "contemporary spin on urban context," and a "tour de force on urbanistic grounds alone. It actually succeeds brilliantly in weaving together disparate parts of the cityscape." 33

When sculptural museums are used in urban neoliberal strategies, commodification of iconic buildings is a common feature. Just like cultural regeneration cannot be separated from property-led regeneration, the intentionality of urban leaders when using iconic museums in their revitalization plans is mainly one of increased economic returns, growth, competitiveness and global visibility. In this context, the role of art is at best secondary and often neglected.

30. Ibid, 43.

31. Ibid, 56.

32. Snyder, "Museums after Bilbao: Neoliberal Public Space at the Denver Art Museum," 2016, 32 .

33. S. Stephens, "Studio Daniel Libeskind and the Davis Partnership Shake up Downtown with a New Addition to the Denver Art Museum," Architectural Record 195, no. 1 (2007), 84. 
"[...] while previously museums were identified by their collections, now this is by their architecture: In other words, the dominant image is the container, rather than the content." 34

Further, one must not forget that when museums are intended as catalysts for urban development, there are usually many negative impacts concerning accessibility and quality of life in urban areas. New museums often attract visitors and energize neighborhoods, but too often residents - and particularly low-income residents - tend to be disregarded. Victoria Newhouse writes that,

"During the last two decades this role has become increasingly frequent [...]. Because major renewal projects normally spearhead gentrification, dislodging low-income populations, they cause tremendous social and economic upheaval and tend to be highly controversial." 35

According to Snyder, the Hamilton Addition was "an integral part of Denver's attempts to transform its downtown, and in particular the Golden Triangle, into habited, "urban villages" intended for upper income residents.",36

"Development skyrocketed in the downtown generally, especially in the LoDo area and other neighborhoods in the northwest portions of downtown. Some development occurred in the Golden Triangle, but not to the same extent as other downtown neighborhoods. Following Denver's planning and building in the Civic Center and Golden Triangle pointed to more interesting research regarding the city's use of arts and culture in urban policy."37

All in all, the Libeskind building in Denver did not turn the city into a worldclass tourist destination. One reason is the intrinsic limitations of urban icons to trigger significant economic change in cities. The other is the change away from spectacular architecture in design theory and away from using spectacular architecture as a tool for urban revitalization. Snyder contends that "there has been a shift in Denver's rhetoric and planning away from monumental building like the Hamilton Addition towards the cultivation of smaller arts institutions or street culture. ${ }^{, 38}$ From iconic buildings to cultural districts to sustainability, there has been a clear evolution in planning and urban strategies in the past ten years. With this development, the meaning of the DAM in Denver has shifted and its influence as an urban revitalization tool has decreased.

34. A. M. Guash and Joseba Zulaika, Learning from the Guggenheim Bilbao (Reno: University of Nevada Press, 2005), 16.

35. Newhouse, Towards a New Museum, 1998, 194.

36. Snyder, "Museums after Bilbao: Neoliberal Public Space at the Denver Art Museum," 2016,162

37. Ibid, 164

38. Ibid, 176. 
"Denver's planning and building in the Civic Center and the Golden Triangle from 2006 to the present, with respect to issues of public space, shows a shift in Denver's conceptualization of "arts and culture" and with that, the decreasing authority of the Denver Art Museum as the icon of culture in Denver." 39

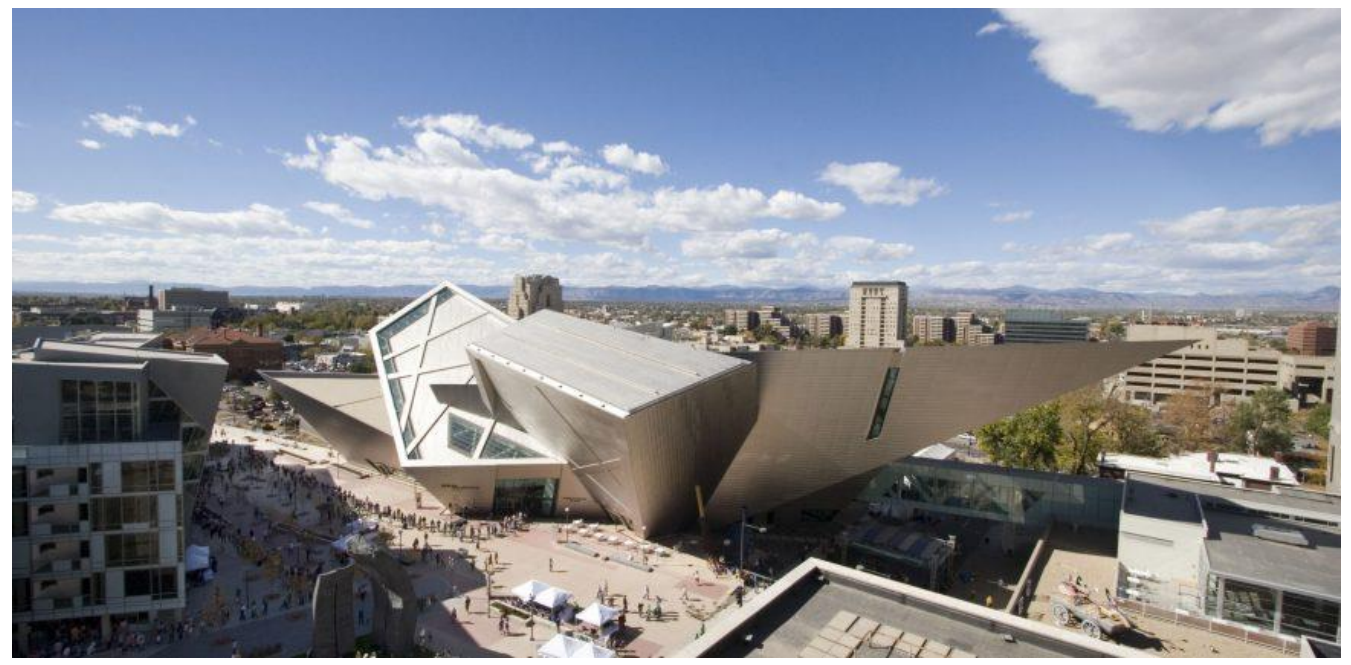

Figure 4. Daniel Liebeskind's Hamilton Addition to the Denver Art Museum (2006)

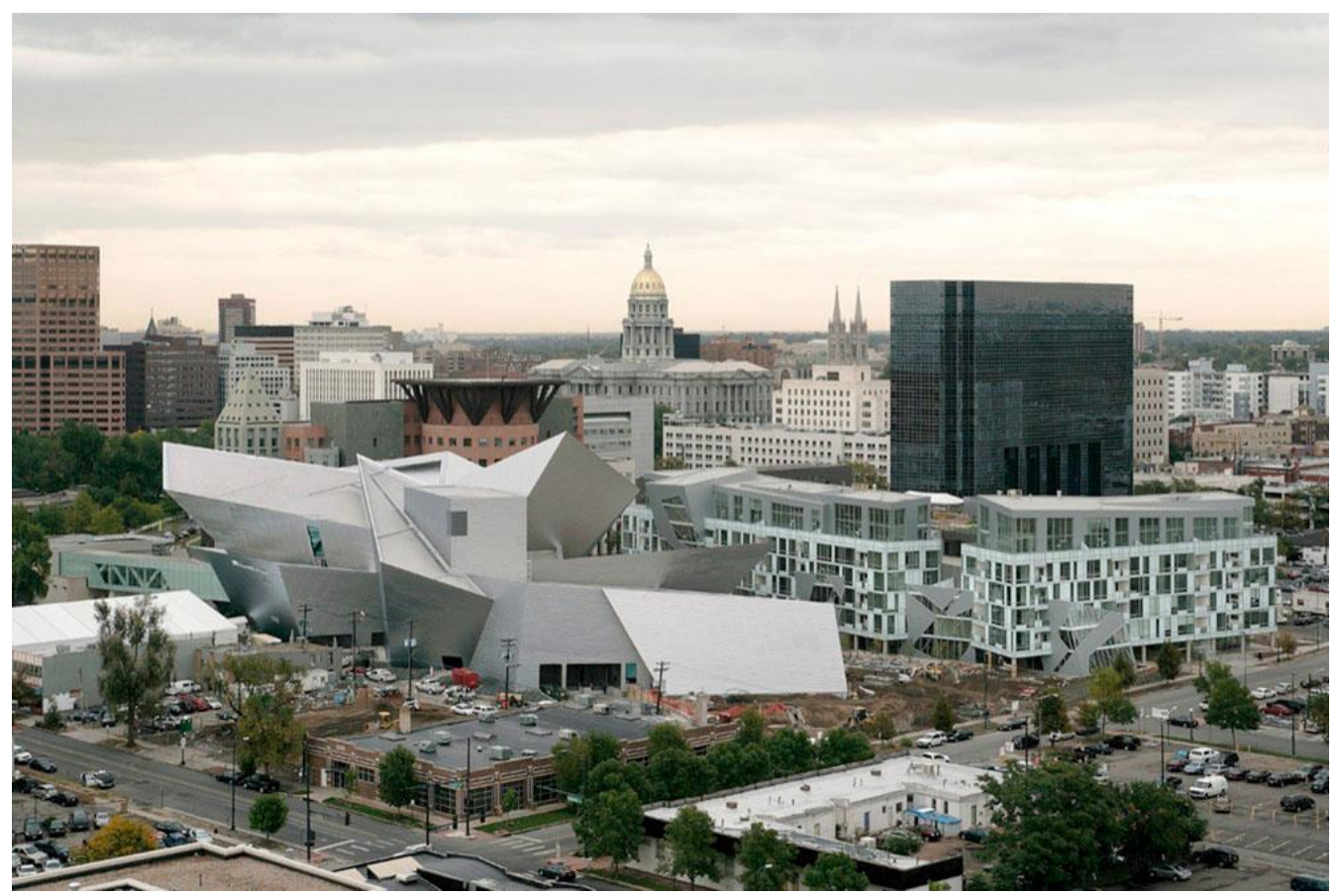

Figure 5. Liebeskind's Museum Building in the City of Denver, Colorado, USA

39. Ibid, 184. 


\section{Helsinki’s Failed Guggenheim Museum}

The Guggenheim Museum Helsinki is a failed project that will not be built. The outcome of the Guggenheim Helsinki's international competition was known in June 2015, with the winning project going to the Paris-based firm Moreau Kusunoki Architectes. However, in Fall 2016, the City of Helsinki voted to cancel the project due to increasing controversy and civic opposition.

The project was perceived as an onerous economic expenditure in Finland. The project came with a $€ 130 \mathrm{~m}$ price tag and a hefty $€ 27 \mathrm{~m}$ licensing fee to the Guggenheim for the privileges of using the Brand, ${ }^{40}$ not to mention the cost overruns that the project would have likely generated, as most megaprojects do. Kaarin Taipale, the co-author of In the Shadow of Guggenheim, a book that analyzed the project challenges, stated:

"If [Guggenheim] is a private enterprise, so it's simply not part and parcel of Finland's welfare society to support that kind of organization with public funds [...]. Everything would be financed by the city - the land, the construction, the upkeep of the building, the salaries, the license fee, everything.",

Finland was in a recession after 2008 and experienced difficulties in pledging to finance the megaproject. The country is considered to be in a "lost generation" due to losses in industrial development, and EU sanctions imposed on Russia, Finland's biggest trading partner. ${ }^{42}$ The cost of the project was the primary reason that it was denounced by opponents. Paavo Arhinmäki, Cultural Minister of Finland, stated that the Ministry would not fund the project, saying,

"We are already cutting money for museums, theatres and orchestras [...]. There is a really tough economic situation. 70 million for construction and a million a year in operating costs, there isn't that kind of money in the culture Budget."43

The assumption of the Guggenheim project was that the money would be provided by external sources such as franchising payment, which would cover the 30 million USD that would be paid to the Guggenheim Foundation for rights to use the name and brand. Arhinmäki also said that all other payments would be funded by taxes:

"Now it looks like everything else is supposed to come from taxpayers [...]. That means that when the National Board of Antiquities (which funds

40. O. Wainwright, Helsinki v Guggenheim: The Backlash against the Global Megabrand is On (The Guardian, 11 September 2014).

41. Taipale in Wainwright, Ibid, 26.

42. K. Ziabari and J. Urpilainen, "Finland's Economy is in the Middle of a "Lost Decade,"'” Fair Observer, 31 October 2014.

43. YLE, Minister Says No Culture Budget for Guggenheim (YLE, 1 December 2012), 12. 
museums in Finland) makes cuts, museums will have to scale back their operations. So the issue should be assessed honestly. This would mean big cuts would have to be made elsewhere in the culture Budget." $" 44$

\section{Failure to Recognize Local Culture and Context}

In the architecture competition by the Guggenheim Helsinki, none of the finalist firms - nor any participating firms - were Finnish, and neither were most of the artists in the Guggenheim collection. Raoul Grunstein, a Finnish artist, also worried that "the meaning of our local artists would be diminished." 45 Richard Armstrong, Director of the foundation and the Guggenheim in New York addressed this issue:

"I felt some defensiveness and some very developed hostility to us, a fear which I was empathetic toward - that the distinct local character of Helsinki would somehow be amalgamated into some sort of gigantic industrial apparatus." 46

Kaarin Taipale echoed the opinion of Armstrong. She stated:

"This is like we are buying a Louis Vuitton bag because it is a famous brand we [Finland] need our own brands." 47

The project's opponents were mainly on the political left, while the right saw it as a boost for Finland, citing the example of the Bilbao Guggenheim, which, according to conventional wisdom, helped transform the Spanish city into a popular art and architectural destination. Dazzled by the promise of the "Bilbao effect," dozens of cities have been courting the Guggenheim every year. But when Helsinki city councillors were asked recently if the museum would benefit Finland as a whole, none agreed strongly, while almost half disagreed. ${ }^{48}$

As The Guardian newspaper informs, Mark Wigley, dean emeritus of the graduate school of architecture at Columbia University and chair of the judges in the international design competition, said the "genuinely dignified" status of the public in the winning design (by Paris-based Moreau Kusunoki Architectes) was "a wake-up call to the Guggenheim and architecture in general."

"I am so bored with 80-year-old white men getting out of their aeroplanes, not knowing anything about the city but pretending to love the clients and dumping one more uninteresting museum on them-"49

44. Ibid, 16.

45. I. Volner, Can the Guggenheim Charm Finland? (The New Yorker, 12 May 2015).

46. Ibid, 29.

47. Ibid, 28.

48. The Guardian, Migrants Building UAE Cultural Hub Working in Prison Conditions (The Guardian, 4 April 2015).

49. Wigley, cited in The Guardian, 2015. 
Architect and urbanist Michael Sorkin, opponent of the Guggenheim Helsinki, criticized the six finalists of the architectural competition. He said:

"My general reaction is that it's all architecture, simply a series of single buildings on a particularly charismatic site. There's nothing unusually extraordinary. I found bizarre the idea that the jury is attempting to preserve the anonymity of the entrants - two kids in my studio more or less figured them out in a few seconds."

Sorkin was the chair of The Next Helsinki (TNH), an international competition that sought innovative ideas for the improvement of the cultural and public space of Helsinki. Launched as an alternative to the controversial Guggenheim Helsinki project, the Next Helsinki "called upon architects, urbanists, artists, and environmentalists to imagine how Helsinki and the South Harbor site allotted to the proposed museum can be transformed for the maximum benefit of the city's residents and visitors," as the official TNH website states:

"We initiated this project out of a sense of both outrage and love. Outrage at the march of the homogenizing multi-national brand culture emblematized by the imperial Guggenheim franchise - the cultural equivalent of Starbucks was what launched us. The feeling of love came from our mutual affection for Helsinki, from a sense that it is a singular place, unique in setting, form, and culture. Understanding the impetus to acquire a Guggenheim as a pursuit of the vaunted Bilbao effect, the idea that some gaudy global repository would put a tired place on the map, we wondered why a city so indelibly fixed in the urban firmament, so superb, would want to surrender such a fabulous site to some starchitect supermarket."

The TNH competition, pitched to "attract innovative ideas about how to more fully meet the city's cultural, spatial and sustainability needs," branded the Guggenheim project a "misguided vanity project, and a symbol of the Finnish capital selling out to an American brand." ${ }^{.52}$ According to The New York Times, the majority of city residents opposed the project and local artists expressed concern about the Guggenheim potentially absorbing the Helsinki City Art Museum. ${ }^{53}$

Call for submissions for TNH opened on September 9, 2014. Deadline for submissions was March 2, 2015. Over 200 international entries were submitted to the Next Helsinki competition from 37 different countries on five continents. The international jury, chaired by Michael Sorkin, announced the competition results on April 20, 2015 in Helsinki, about two months prior to the outcome of the official Guggenheim Helsinki competition. The jury was most excited about

50. Z. Edelson, Michael Sorkin on the Guggenheim, Museum Culture, and "The Next Helsinki” Competition (Arch Daily, 27 January 2015).

51. TNH - The Next Helsinki.

52. Ibid.

53. Volner, Can the Guggenheim Charm Finland?, 2015. 
entries that suggested building on existing resources, and that tried to capture emergent urban trends and tendencies in the city.

\section{Lack of Focus on Sustainability and Creativity}

The six finalists' architectural designs of the Guggenheim Helsinki were criticized as being uncreative and lacking in focus on sustainable bioeconomy, which Finland leads in. ${ }^{54}$ Finalists' final designs were repeatedly reminiscent of modern architecture, such as

"light as a beacon, industrialized portal frames with a modern twist with piano roofs and one entry that resembles a lotus flower or something resembling flora which had been so overdone." 55

Architecture needs to be responsive and be considered as a form of "critical regionalism," which has been lacking in a significant number of projects:

"The renderings look amazing no doubt, but how exactly does this incorporate the bioeconomy and sustainability that was stressed upon in the brief? And did any of the finalists bother to incorporate the rich heritage site that it sits on? Being the main reason for its selection in the first place?"56

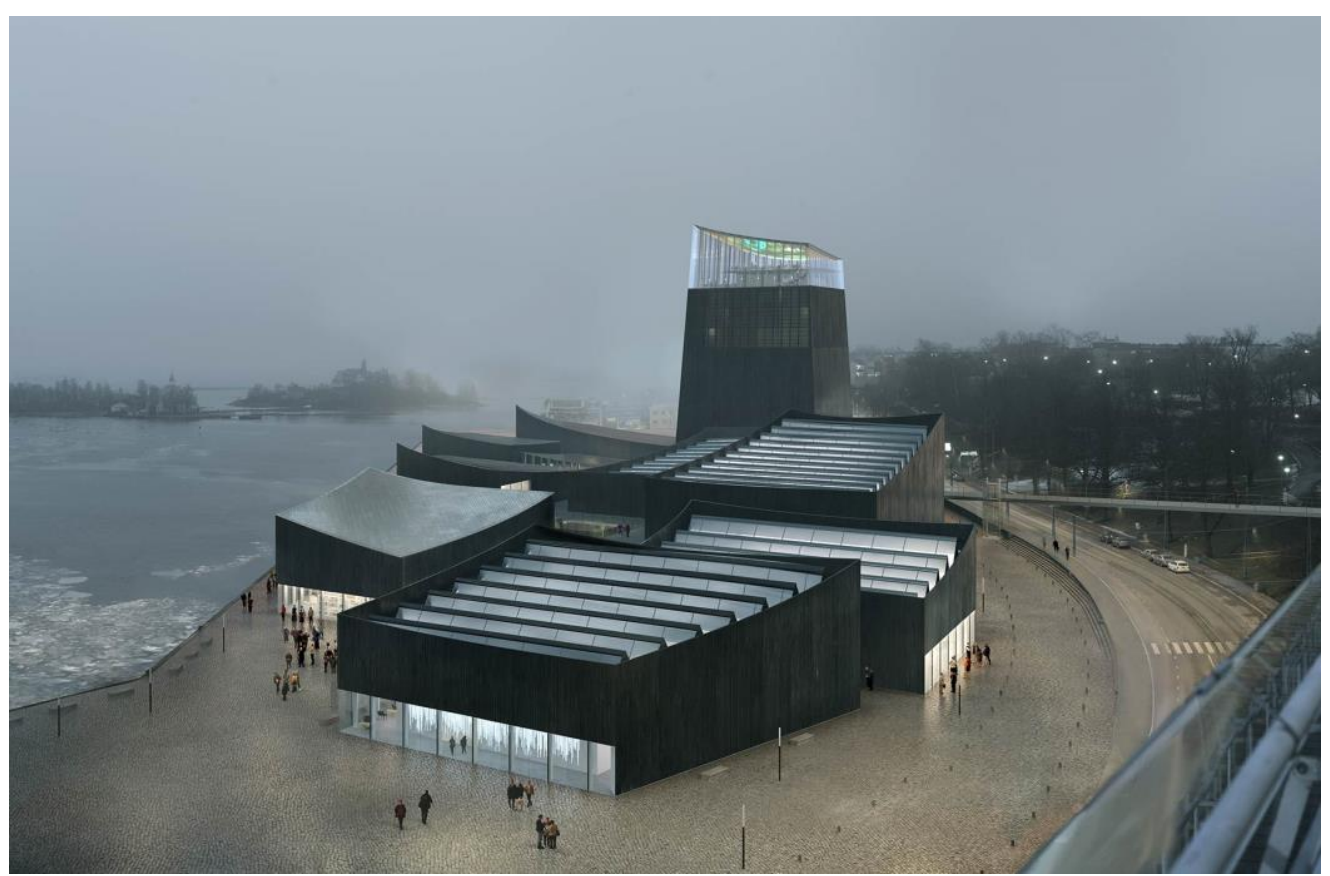

Figure 6. The Winning Design for a New Guggenheim Museum in Helsinki, Finland, by Moreau Kusunoki (2015) - Never Built

54. Guggenheim Helsinki. About (Guggenheim Helsinki Design Competition, 2014).

55. Z. Kalla, To Guggenheim or not to Guggenheim Helsinki ?... That is the Question (Arch2o, 2014), 51.

56. Ibid, 53. 


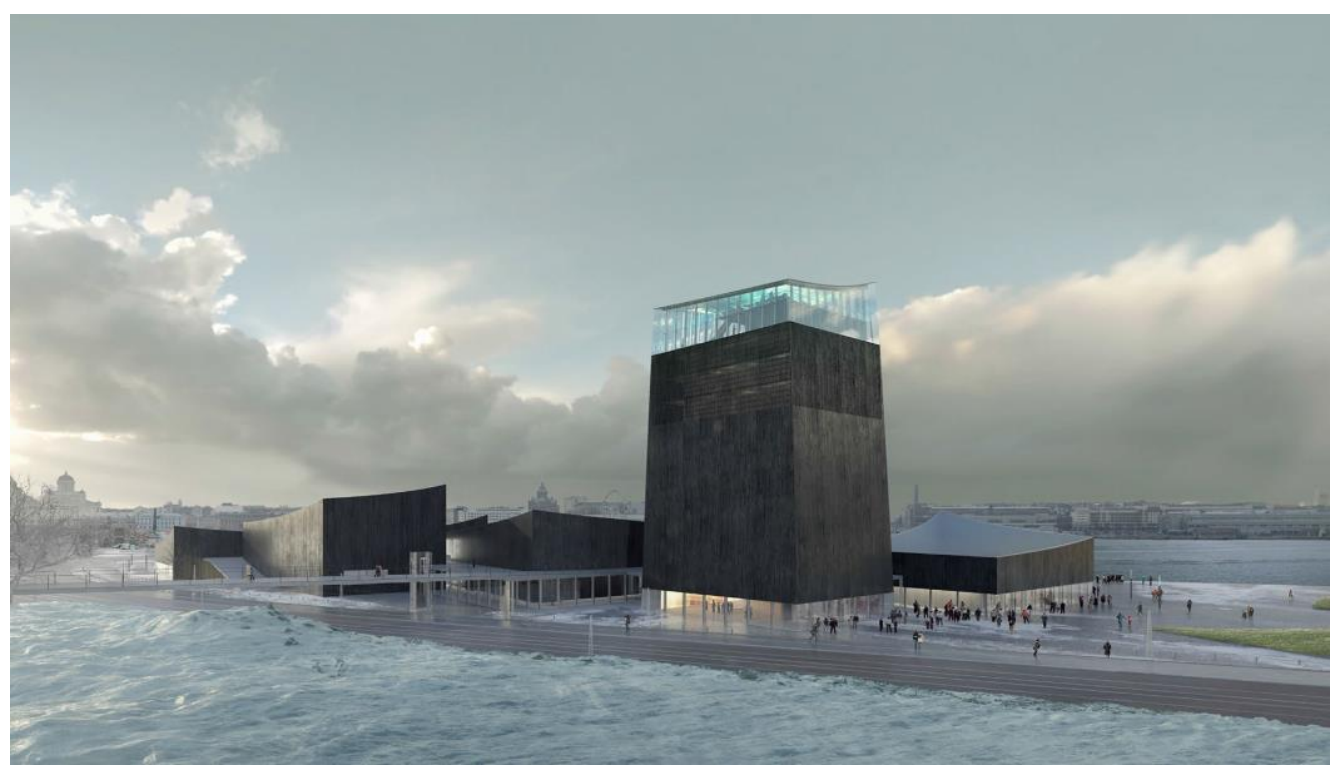

Figure 7. The Guggenheim Helsinki Winning Design and the City in the Background

\section{Abu Dhabi and Dubaization}

The Dubaization of Abu Dhabi includes a new Guggenheim Museum, designed by Frank Gehry, originally set to open in 2012, then in 2017, and still not completed as of March 2019 (Figures 8-9). The Guggenheim in Abu Dhabi is twice the size of the museum in Bilbao, twelve times the size of the Frank Lloyd Wright Guggenheim in New York. Carol Vogel in The New York Times refers to this Gehry design as "a graceful tumble of giant plaster building blocks and translucent blue cones." $" 57$

Most Arab world cities are competing to imitate Dubai in its unprecedented effort to build the tallest, the biggest and the largest ever built architectural and urban statements. This phenomenon can be best described as "Dubaization," the process of urbanizing a city with futuristic, pioneering architecture. Dubaization is qualitatively similar to the "Bilbao effect," and part of the "icon project," and it has spread to other cities, even outside of the Gulf area, such as Istanbul and Vancouver. Dubaization triggers crucial questions: What are the consequences of this urbanization strategy on the future of Arab cities? What kind of social life will emerge out of this development? Is this just an elite-driven process of constructing, reconstructing and deconstructing identities and the territorial outlook of Arab cities? And also, is there any future for sustainability in the developmental strategies of Arab and Middle Eastern cities?

Dubai, as a model of urban development, is based primarily on images and icons rather than sustainable concepts and processes. Major conflicts are resulting from this, including failing to adopt sustainability, limited interpretation of

57. C. Vogel, A New Art Capital, Finding its own Voice. Inside Frank Gehry's Guggenheim Abu Dhabi (The New York Times, 4 December 2014). 
globalization and degradation of locality. Arguably, Arab cities need to consider a more holistic approach for its sustainable strategic development. Architecture as a domain and creative reflection of local culture can be used as a vehicle to maintain local culture and interact with the global apetite for knowing "the other." The main condition for these architectural products to be exposed to the other is that they should be coming from a deep and original local vision rather than being exemplars of a globally crafted strategy. The multiple controversies and disruptions associated with the Guggenheim Abu Dhabi indicate errors and failures in planning, policy and implementation.

\section{Abuses on Foreign Workers}

Foreign workers in Abu Dhabi comprise $85 \%$ of the workforce, most originating from nearby countries such as Bangladesh, Pakistan, Nepal, India and Sri Lanka. According to a PriceWaterhouseCoopers compliance report, ${ }^{58} 86 \%$ of the workers paid illegal recruitment fees to agents, while $92 \%$ said they paid for their own relocation fees including visa, accommodation and travel expenses. These statistics have increased since the previous report, from $75 \%$ and $72 \%$ respectively. Many of these workers are young men who were led to believe they would be working high-paid construction jobs.

Despite their payment, these workers live and work in dire conditions. According to Human Rights Watch, ${ }^{59}$ some workers were under the impression that they would be working as hotel employees or waiters only to realize they would be working far less lucrative jobs in the construction industry.

The Guggenheim, in conjunction with NYU Abu Dhabi and the Louvre, insisted on the guarantee of worker's rights to prevent discord from board members and donors. Despite this assurance, The Guardian released a 3-month investigative report on the work and living conditions, and found the following: ${ }^{60}$

- Companies withhold the passports of migrant workers, trapping them in the UAE.

- Thousands of workers are living in substandard conditions elsewhere in the UAE, in apparent breach of the TDIC's (a developer of major tourism destinations in Abu Dhabi) pledge to house them all in its model Saadiyat accommodation village.

- Dozens of workers were deported in 2014 for striking over pay and conditions.

- Mobile-phone video footage of a riot in August shows dozens of men roaming the camp armed with metal spears and planks spiked with nails, with men seen jumping out of windows to avoid the conflicto.

- A worker who claims he lost his leg while building luxury villas has been forced to live on the top floor of a migrant camp for a year. He only

58. Cited in B. Mauk, Abu Dhabi's High Cost of Culture (The New Yorker, 28 January 2014).

59. Cited in Mauk, Abu Dhabi's High Cost of Culture, 2014.

60. The Guardian, Migrants Building UAE Cultural Hub Working in Prison Conditions, 2015. 
received a prosthetic leg last month and has been reliant on the Red Crescent for medical support. His claim for compensation, and request for ground-floor accommodation, have been rejected.

\section{Possibility of Downsizing the Museum}

The original cost of the Guggenheim was said to be around $€ 800 \mathrm{~m}$ out of the $€ 27 \mathrm{~b}$ budget for the cultural district. ${ }^{61}$ Ramin Salsali, honored as patron of the arts by the UAE vice president Sheik Mohammed bin Rashid Al Maktoum, said that the project would not stimulate the local economy and cultural development because Abu Dhabi does not need the museum to enhance its reputation. He stated:

"The Guggenheim effect is sexy when you are not on the radar. When you are Bilbao. But Abu Dhabi today - I'm sorry to say, but the Guggenheim should pay Abu Dhabi to be there, not vice versa. Does Abu Dhabi need the Guggenheim still? I don't believe so... The luck is that the delay may provoke a reconsideration of why we should have a Guggenheim of that scale, with that amount of money. Let us downsize it." 62

\section{Religious and Political Censorship}

In Abu Dhabi, and specifically in Saadiyat Island (the location of the new Guggenheim), only purely ornamental art is permitted, ${ }^{63}$ while modern art to be exhibited in the Guggenheim museum is generally regarded as "largely liberal, tolerant and exuberant." $" 64$ This contrast between local culture and modern art would create a clash in society, where "cultural biases threaten to divide the project philosophically while practical differences suggest that the users and providers also disagree about the eminence of economic or aesthetic interests." ${ }^{.65}$ Verena Formanek, Senior Project Manager of the Guggenheim Abu Dhabi, admitted that the compiling process of contemporary art is difficult because,

"[It's] completely different in the process of acquiring the work because we represent the government. This is government money. We want to accelerate

61. A. Shadid, An Ambitious Arab Capital Reaffirms its Grand Cultural Vision (The New York Times, 24 January 2012).

62. D. Batty, Guggenheim Delay Raises Big Question: Is Abu Dhabi Ready for Modern Art? (The Guardian, 27 April 2012).

63. Spiegel Online International, Krens' Museum for Global Contemporary Art: Guggenheim Abu Dhabi will be 'Pharaonic' (Spiegel Online, 27 March 2008).

64. C. Skluzacek, Universality and its Discontents: The Louvre and Guggenheim Abu Dhabi as a Case Study in the Future of Museums (Macalester College Art History Honor Projects, 2010), 35 .

65. Ibid, 43. 
slowly, not beginning with the contemporary in the sense that we shock people and no one ever came back here." ${ }^{66}$

However, she also noted that the delay in the construction of the museum gave the government time to educate the public and prepare them for the art that would be exhibited in the museum. Rita Aoun Abdo, Saadiyat's Cultural Director, has noted that museums need to develop organically within the local culture, or else their survival is compromised. ${ }^{67}$

Apart from religious censorship, there are also worries that there will be political censorship in the Guggenheim after the Arab Spring movements. Although the political movement largely passed by the UAE, ${ }^{68}$ the country introduced internet restrictions in 2012 on the use of social media to organize protests and imprisoned a large group of Islamists who were charged on plotting a coup in 2013. One example of political censorship includes the sacking of Jack Persekian as the Director of Sharjah Biennial in 2011, which planned to display a picture considered offensive to the ruling Sheikh in Sharjah. "No one anticipated that this [Arab Spring] would happen. I think everyone was thinking about religious issues, no one thinking of this powerful political aspect."70

\section{Adverse Effects due to Reclamation and Breakwaters}

In order to accommodate the Guggenheim Abu Dhabi, along with the Louvre and a Performing Art Centre, new lands and breakwaters are being created. ${ }^{71}$ Previous breakwaters in other places are known to stagnate oceanic flow around the area and cause environmental problems. When the flow is stagnated, waste cannot flow out of the area and nutrients cannot flow in, hence further deteriorating the environment along the shore. The turbidity and sedimentation levels along the shores of Saadiyat Island could also increase, which would further harm the aquatic life as insufficient oxygen is dissolved into the water.

Multiple floodings have also occurred during the reclamation projects. According to the environmental impacts report on dredging and reclamation issued by Terra et Aqua, in a settlement pond for the trailing suction hopper dredger (TSHD) has extremely unsatisfactory performance:

"The flow over the pond constantly changed because of differences in reclamation activities and locations. Therefore management of the weir boxes

66. Batty, In Abu Dhabi, they Call it Happiness Island. But for the Migrant Workers, it is a Place of Misery (The Guardian, 21 December 2013).

67. Batty, Migrants Building UAE Cultural Hub 'Working in Prison Conditions' (The Guardian, April 4, 2015).

68. A. Dhabi, Why the Arab Spring Never Came to the U.A.E. (Times, 18 July 2011).

69. A. Mcclellan, "Museum Expansion in the Twenty-First Century: Abu Dhabi," Journal of Curatorial Studies Journal of Curatorial Studies 1, no. 3 (2012): 271-293.

70. Wells cited in Batty, 2015.

71. E. Taelman, "Saadiyat Island Tourist Develoment Project: Dredging and Reclamation Works in an Ecologically Sensitive Area," Terra et Aqua 116 (2009): 3-11. 
and maintenance of channels and scum booms had to be organised very carefully [...]. During the course of the project, however, the settlement pond filled up with material. As a result of the constant flow of water over the pond, the material could not be removed and the settling capacity of the pond decreased. Furthermore, the settlement pond was part of the design of the island, and needed to be reclaimed as well. As reclamation progressed, the remaining area for settling decreased and the height of the weir boxes was no longer sufficient to hold enough capacity to ensure tailwater quality [...]. Closer investigation showed that depth of the trenches was still not according to the screen requirements.", 72

\section{Adverse Effects on Marine Life}

Sensitive marine communities, including mangroves, seagrass and coral communities around the area are being adversely affected by dredging activities. For mangrove death to occur, the sedimentation rates of greater than $15 \mathrm{~mm}$ per year just need to smother the aerial roots where gas exchange occurred. Despite the modelling of sediment accumulation indicating little risk of smothering of mangrove roots, mangroves located inside the boundaries of reclamation areas are likely to suffer due to both reclamation and dredging. While mangroves and seagrass are very sensitive to the salinity and acidity of the surrounding water, coral communities are very sensitive to sediment load on surface water. Impervious surfaces, such as roadways, increase the runoff rates and carry water mixtures containing pollutants; these waters are eventually discharged into coastal waters. Coral communities are harmed in this process, threatening biodiversity in the área. $^{73}$

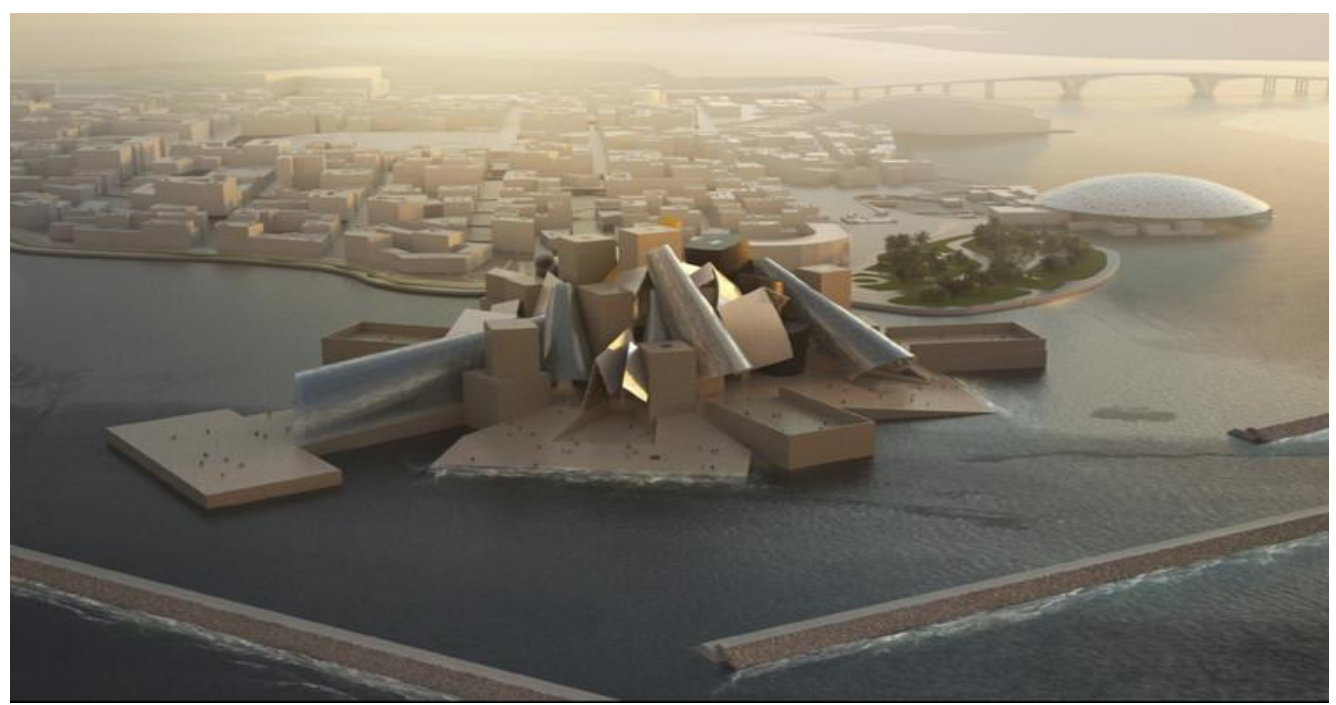

Figure 8. The Guggenheim Abu Dhabi by Frank Gehry (2017) in Saddiyat Island

72. Ibid, 31 .

73. Ibid, 36 . 


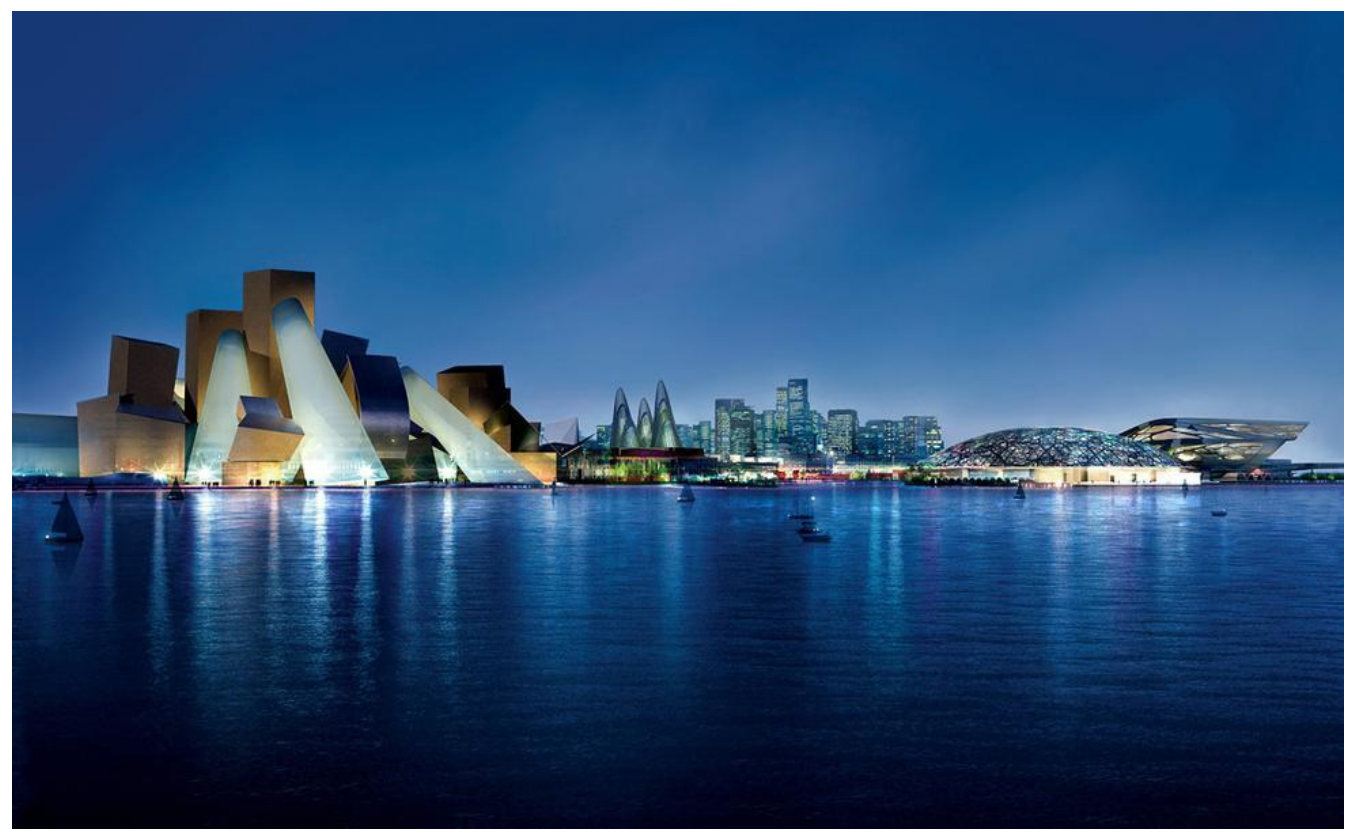

Figure 9. The Guggenheim Abu Dhabi at Sunset with the City in the Background

\section{The Fading Away of the Bilbao Effect}

In 2007, del Cerro Santamaría warned that iconic architecture could be replaced as the hegemonic discourse of urban revitalization and, with this development, the Bilbao Effect would fade away. ${ }^{74}$ Along these lines, architectural critics such as Michael Kimmelman have come to understand that the Bilbao Effect sat on shaky foundations:

"The truth is, the Bilbao effect is largely a myth. Frank Gehry's museum alone didn't turn around that city. It capped decades of civic renewal. Flashy, even brilliant buildings rarely rejuvenate neighborhoods or guarantee crowds and cash just by virtue of their design [...] Sadly, museums, like cities, have squandered fortunes praying to this false idol. They still do."75

The example of the new Ordos Art Museum in Inner Mongolia, beautifully designed by MAD, a prestigious firm of Beijing architects, suggests (not too surprisingly) that just building a terrific museum is not enough to ensure success. The city of Ordos has sprung up fast and is relatively wealthy, thanks to discoveries of oil and gas, but the museum has no collections and precious few plans for exhibitions. No wonder it is devoid of visitors.

Even before actual construction, the Guggenheims in Helsinki and Abu Dhabi have attracted significant criticism, as this paper has shown. The projects could be questioned along three main lines: (1) iconic architecture is no longer the

74. del Cerro Santamaría, Bilbao. Basque Pathways to Globalization, 2007.

75. M. Kimmelman, Why is This Museum Shaped Like a Tub? (The New York Times, Art and Design Section, 23 December 2012). 
hegemonic visual discourse in urban revitalization; (2) the franchise model imposed by the Guggenheim means that local officials have no autonomy to make major decisions on matters from exhibition calendars, to budgets and investments; and (3) local cultural identities are usually neglected under a foreign global arts model. In addition, the environmental impacts of the projects may not be negligible. The Abu-Dhabi project has also been controversial around issues of workers's rights and labor conditions. Iconic megaprojects trigger many controversies, including cost overruns, negative environmental impacts, gentrification risks, drawbacks of top-down cultural engineering, neglect of local cultural identities, and uncertain economic success. None of these externalities bode well for cities that are counting on instant icons to salvage them during times of economic malaise.

Despite the media success of the Bilbao Guggenheim, the Bilbao effect has proven to be difficult to replicate in most places, even for Frank Gehry. On the other hand, some architectural icons, such as Gehry's Stata Center at MIT, work well with no Bilbao effect -- most MIT scientists working in the building praise its playful and inventive feel, as I have personally witnessed. ${ }^{76}$ Cooper Union alum Daniel Libeskind's jagged edges, sharp angles and complex geometries (the extension to the Denver Art Museum, the Royal Ontario Museum in Toronto or the Danish Jewish Museum in Copenhagen) have not had the universal acclaim of his Jewish Museum Berlin, an illustration that success, impact and visitor attraction are not necessarily a function of a building's spectacular design. Many works by Shigeru Ban or Tadao Ando are excellent examples of highly admired and successful architecture in the antipodes of iconic buildings designed to stun.

Woronkowicz et al analyzed new cultural facilities built in the U.S. between 1994 and 2008, a building boom for museums and other arts institutions. ${ }^{77}$ According to their analysis, the Bilbao Effect did not materialize in most cases. There has been a decrease in poverty rates and an increase in property in communities where new cultural centers or expansions were built, but poorer residents also suffered displacement in those areas. In addition to the usual gentrification effect caused by cultural megaprojects, the researchers show that supply may have outstripped demand and cities have been left with the responsibility to maintain or even pay for cultural centers that they don't entirely need.

Further, the analysis shows that expansions and new museum projects don't have spillover effects one way or the other (positive or negative) for nearby cultural institutions. In addition, the authors explain that leaders involved in building cultural megaprojects depend on "inside knowledge" obtained from their own experiences, and those of their collaborators' experiences. "What tends to be absent in their thinking, however [...] is "outside knowledge" regarding the distribution of projects that did not go as planned," the book continues. ${ }^{78}$ 2007).

76. R. Campbell, Does Gehry's Stata Center Really Work? (Bloomberg Business, 19 June

77. Woronkowicz, Building Better Arts Facilities: Lessons from a U.S. National Study, 2015.

78. Ibid, 56. 
Cost overruns and project delays are typical symptoms associated with cultural megaprojects. In the cases analyzed in Woronkowicz (2015), a full 91 percent of performing-arts centers built during the study period went over budget. Of the projects they studied, 54 percent featured lower revenues than projected, while 59 percent featured higher expenses. What the research shows is a gap in cultural facilities management lacking level-headed analysis that leads to misplaced expectations and mistakes resulting in budget shortfalls and cost overruns. $^{79}$

In summer 2017, the Centro Botín opened in Santander, Spain. Located just an hour from Bilbao, the contemporary art centre was designed by Renzo Piano, a "starchitect" who is no stranger to flashy, monumental design. As Hune-Brown explains:

"The museum is an elegant, striking structure, but its creators have been eager to tamp down any Bilbao-related rhetoric about civic transformation. According to the Botín foundation's president, the museum was built for the people of the city, not to "create an icon." It is nearly invisible from within the city itself $-\mathrm{a}$ "self-effacing" building according to one architecture critic. The building feels like a public affirmation that the heady days in which we talked about architecture saving cities are over. When Piano was asked about his approach to the design, he didn't mince words. "I suppose our strategy was the opposite of the Guggenheim," he said. "How many Bilbao effects can you have after all?" 80

\section{Conclusions}

Denver, Helsinki and Abu Dhabi, the cases examined in this paper, add to the list of cities around the world that attempted urban transformations similar to Bilbao's. We know that the Helsinki Project was cancelled and will not materialize, but we wanted to show the numerous controversies and civic opposition it triggered during the planning and design phases. In the case of Denver, urban planning developments in the years since the opening of the Libeskind addition to the DAM in 2006 have displaced the Denver Art Museum to the sidelines in local efforts at urban improvement. In Abu Dhabi, the new Guggenheim will play in a complex environment within the context of an increasing diversification of the local economy and, if its fate is similar to Masdar City's eco-experiment in the outskirts of Abu Dhabi, the success of the new museum is far from guaranteed.

79. Ibid, 61.

80. Hune-Brown, Is this the End of Starchitecture?, 2017. 
Even if Bilbao is considered a very successful case of image reconstruction via iconic architecture (something that by itself did not solve many of the structural and socio-economic problems of the city), the Bilbao Effect was largely a failure and has clearly faded away. The failure and the fading away of the "Bilbao Effect" owes to the limitations of existing political rationality and decisión-making processes at times when globalization put pressure on urban leaders to redevelop and become globally visible. It also owes to a poor understanding by outsiders of the context and true reasons behind Bilbao's urban revitalization success, which have little to do with iconic architecture: they owe to a sound economic policy by the financially autonomous Basque government and a well-crafted and comprehensive revitalization plan of which the Guggenheim was just a very small and ad-hoc component. Further, while Bilbao has been more successful than other cities at branding and image change, the realities of urban life in Bilbao remain subject to the complexities, contradictions and shortcomings of the neoliberal model of urban development, including precarization of the labor market and severe socio-economic inequality. Iconic architecture has brought tourists to Bilbao, but it has contributed nothing to solving the structural problems of Bilbao's urban economy.

Bilbao's economic performance after the opening of the Guggenheim broadly follows the ups and downs of economic cycles, a clear indication of both the embeddedness of cities - and iconic megaprojects - in multiple scales of socioeconomic action and the limited power of architectural icons to explain development, competitiveness and urban economic change. Institutional contexts, specific policy instruments and territorially grounded social dynamics give rise to distinct patterns of iconic megaproject development and help explain the degree to which such megaprojects succeed or fail.

On the other hand, in the hypothetical case that the star of the Bilbao Guggenheim begins to dim and visitors cease to arrive in Bilbao in large numbers, the consequences for the Basque city would not amount to significant economic decline, as the museum represents just 2.2 percent of the Bilbao economy. Cities are complexly determined formations, and a spectacular building alone, even if projected by experts and the media on a worldwide scale, is not usually capable to shift their fortunes in fundamental ways.

In addition, not every city is well positioned to be "put on the map," especially second or third-tier cities that are comparable to Bilbao in terms of size but are located off main routes and flows of people and commerce. Bilbao is located in one of the top three tourist destinations in the world (Spain), which has been a factor in the museum's spectacular ability to attract visitors. Spain receives about 85 million visitors annually, of which approximately 2.5 million tour the Basque Country, with around one million visiting the Guggenheim Museum in Bilbao.

To be sure, cities should not expect to be able to replicate the success of Bilbao just by implementing fashionable urban policy marketized via appropriate global media discourses. Each city has a local history, a region within which it develops, and a specific political make-up that influences local decision-making processes. Cities and regions around the world partially adhere to their own specific logic of development. 
Each city shows particular features that contribute to explaining decline, and each may need localized strategies for redevelopment. Applying the standard elements in the revitalization mix, including iconic megaprojects, to cities around the world may be unavoidable due to rapid and acritical adoption of policy discourses from center to periphery. However, expecting to replicate a city's success by merely adopting such strategy is often a recipe for disappointment.

Twenty-two years after the opening of the Guggenheim in Bilbao, the Bilbao Effect has faded away and the inflated claims of this age of urban icons no longer hold. When every city seems to boast a spectacular museum, the strategy of building cultural megaprojects has diminishing returns. In this paper, we have tried to show and explain the shortcomings and failures of this mode of urban development. We need to work in favor of other approaches and models where the traditionally overlooked synergies between research-based evidence, management and urban governance for holistic sustainability become a priority area for urban and regional policy-makers to address.

\section{Bibliography}

Alsdorf, B. Collections Curatorial Assistant for the Guggenheim Foundation. Guggenheim Foundation, 2002. Retrieved from: https://bit.ly/2kDZRqp. [Accessed 16 October 2017].

Batty, D. Guggenheim Delay Raises Big Question: Is Abu Dhabi Ready for Modern Art? The Guardian, 27 April 2012. Retrieved from: https://bit.ly/2kugOUl. [Accessed 23 May 2018].

. In Abu Dhabi, they Call it Happiness Island. But for the Migrant Workers, it is a Place of Misery. The Guardian, 21 December 2013. Retrieved from: https://bit.ly/1k vFaCI. [Accessed 28 May 2018].

. Migrants Building UAE Cultural Hub 'Working in Prison Conditions'. The Guardian, April 4, 2015, Retrieved from: https://bit.ly/1EXb6fW. [Accessed 3 July 2015].

Blakemore, E. Museum Building is Booming in the United States. Smithsonian.com, 11 April 2016. https://bit.ly/2kIaEzL.

Brown, J. New Denver Art Museum Reflects Rocky Mountains. PBS Newshour, October, 5, 2006. http://www.pbs.org/newshour/bb/entertainment-july-dec06museum_10-05/.

Campbell, R. Does Gehry's Stata Center Really Work? Bloomberg Business, 19 June 2007. http://www.bloomberg.com/bw/stories/2007-06-19/does-gehrys-stata-centerreally-work-businessweek-business-news-stock-market-and-financial-advice.

del Cerro Santamaría, G. Bilbao. Basque Pathways to Globalization. London: Elsevier, 2007. . ed. Urban Megaprojects. A Worldwide View. Bingley: Emerald, 2013.

Dhabi, A. Why the Arab Spring Never Came to the U.A.E. Times, 18 July 2011. Retrieved from: https://bit.ly/2kGEgxy. [Accessed 29 May 2015].

Edelson, Z. Michael Sorkin on the Guggenheim, Museum Culture, and "The Next Helsinki" Competition. Arch Daily, 27 January 2015. Retrieved from: http://www.arc hdaily.com/591932/michael-sorkin-on-the-guggenheim-museum-culture-and-thenext-helsinki-competition/. [Accessed 27 May 2015].

Fainstein, S. The City Builders. Property Development in New York and London, 1980-2000. Kansas: University Press of Kansas, 2001. 
Guash, A. M. and Joseba Zulaika. Learning from the Guggenheim Bilbao. Reno: University of Nevada Press, 2005.

Guggenheim Helsinki. About. Guggenheim Helsinki Design Competition, 2014. Retrieved from: https://bit.ly/2maHIkl. [Accessed 28 May 2015].

Harvey, D. "From Mangerialism to Entrepreneurialism: The Transformation in Urban Governance in Late Capitalism." Geografiska Annaler 71, no. 1 (1989).

Healey, P., S. Davoudi, S. Tavsanoglu. Rebuilding the City: Property-led Urban Regeneration. London: Chapman \& Hall, 1992.

Hune-Brown. Is This the End of Starchitecture? Azure, 18 August 2017.

Ivy, R. "Architecture for Art's Sake." Quoted in A. Wilson Lloyd. Atlantic Monthly 287 (2001): 85-8. https://www.azuremagazine.com/article/is-this-the-end-of-starchitec ture/.

Jencks, C. The Iconic Building. New York, NY: Rizzoli, 2005.

Kalla, Z. To Guggenheim or not to Guggenheim Helsinki ?... That is the Question. Arch2o, 2014. Retrieved from: http://www.arch2o.com/guggenheim-helsinki-3/. [Accessed 29 May 2018].

Kamin, B. How Stellar are 'Starchitects'? Chicago Tribune, 27 January 2002. http://artic les.chicagotribune.com/2002-01-27/news/0201270415_1_new-dorm-starchitectsnew-york-city-designer.

Kimmelman, M. Why is This Museum Shaped Like a Tub? The New York Times, Art and Design Section, 23 December 2012. https://nyti.ms/2kGjNcc

Klebnikov, A. Museums Inc. Forbes, 8 January 2001.

Lindsay, G. The Denver Art Museum and the Bilbao Effect. UC Berkeley, 2013.

Mauk, B. Abu Dhabi's High Cost of Culture. The New Yorker, 28 January 2014. Retrieved from: http://www.newyorker.com/business/currency/abu-dhabis-high-costof-culture. [Accessed 27 May 2015].

McClellan, A. The Museum from Boullée to Bilbao. Berkeley: The University of California Press, 2008.

"Museum Expansion in the Twenty-First Century: Abu Dhabi." Journal of Curatorial Studies Journal of Curatorial Studies 1, no. 3 (2012): 271-293.

McNeill, D. The Global Architect: Firms, Fame and Urban Form. New York: Routledge, 2009.

Newhouse, V. Towards a New Museum. New York: Monacelli Press, 1998.

Plaza, B. and Silke N. Haarich. "Museums for Urban Regeneration? Exploring Conditions for their Effectiveness." Journal of Urban Regeneration and Renewal 2, no. 3 (2009): 259-271.

Pogrebin, R. British Architect Wins 2007 Pritzker Prize. The New York Times, 28 March 2007. [Accessed May 2018].

Rybczynski, W. "The Bilbao Effect.” Atlantic Monthly 290, no. 2 (2002): 138-42. When Buildings Try Too Hard, Wall Street Journal, 22 November 2008. http://www.wsj.com/articles/SB122731149503149341.

Shadid, A. An Ambitious Arab Capital Reaffirms its Grand Cultural Vision. The New York Times, 24 January 2012. Retrieved from: https://nyti.ms/2h0pqKC. [Accessed 27 May 2015].

Skluzacek, C. Universality and its Discontents: The Louvre and Guggenheim Abu Dhabi as a Case Study in the Future of Museums. Macalester College Art History Honor Projects, 2010, 1-72. Retrieved from http://digitalcommons.macalester.edu/art_ honors/1/. [Accessed 23 May 2015]. 
Smyth, H. Marketing the City. The Role of Flagship Developments in Urban Regeneration. London: Routledge, 2015.

Snyder, P. Museums after Bilbao: Neoliberal Public Space at the Denver Art Museum. Wesleyan University, 2016.

Spiegel Online International. Krens' Museum for Global Contemporary Art: Guggenheim Abu Dhabi will be 'Pharaonic'. Spiegel Online, 27 March 2008. Retrieved from: http://www.spiegel.de/international/world/krens-museum-for-global-contemporaryart-guggenheim-abu-dhabi-will-be-pharaonic-a-543601.html. [Accessed 29 May 2015].

Stephens, S. "Studio Daniel Libeskind and the Davis Partnership Shake up Downtown with a New Addition to the Denver Art Museum." Architectural Record 195, no. 1 (2007).

Taelman, E. "Saadiyat Island Tourist Develoment Project: Dredging and Reclamation Works in an Ecologically Sensitive Area." Terra et Aqua 116 (2009): 3-11.

The Guardian. Helsinki v Guggenheim: The Backlash against the Global Megabrand is On. The Guardian, 11 September 2014. Retrieved from: https://bit.ly/2kgxtKT. [Accessed May 2018]. . Migrants Building UAE Cultural Hub Working in Prison Conditions. The Guardian, 4 April 2015. Retrieved from: https://bit.ly/2mek0UB. [Accessed May 2018].

TNH - The Next Helsinki. http://www.nexthelsinki.org.

Vogel, C. (2014) A New Art Capital, Finding its own Voice. Inside Frank Gehry's Guggenheim Abu Dhabi. The New York Times, 4 December 2014. https://nyti.ms/ $1 \mathrm{zA} 8 \mathrm{ttV}$.

Volner, I. Can the Guggenheim Charm Finland? The New Yorker, 12 May 2015. Retrieved from: https://bit.ly/1ROXZSj. [Accessed 28 May 2018].

Wainwright, O. Helsinki v Guggenheim: The Backlash against the Global Megabrand is On. The Guardian, 11 September 2014. Retrieved from: https://bit.ly/1D0BNgw. [Accessed 29 May 2018].

Webb, W. "Architecture for Art's Sake." Quoted in A. Wilson Lloyd. Atlantic Monthly 287 (2001): 85-8.

Wilson Lloyd, A. “Architecture for Art's Sake." Atlantic Monthly 287(2001): 85-8.

Woronkowicz, J. et al. Building Better Arts Facilities: Lessons from a U.S. National Study. London: Routledge, 2015.

YLE. Minister Says No Culture Budget for Guggenheim. YLE, 1 December 2012. Retrieved from: https://bit.ly/2kw2FGa. [Accessed 28 May 2018].

Ziabari, K. and J. Urpilainen, J. "Finland's Economy is in the Middle of a "Lost Decade."” Fair Observer, 31 October 2014. Retrieved from: https://bit.ly/2lKiHMQ. [Accessed 29 May 2018]. 
